Luchyk Svitlana, Doctor of Sciences (Economics), Professor, Chernivtsi Institute of Trade and Economics of Kyiv National University of Trade and Economics,

Chernivtsi, Ukraine

ORCID: 0000-0003-0757-1140

Researcher ID: V-7133-2017

Luchyk Margaryta, $\mathrm{PhD}$ in Economics, Kyiv Cooperative Institute of Business and Law, Kyiv, Ukraine ORCID: 0000-0002-4822-5407 Researcher ID: K-6129-2018

\title{
CURRENT TRENDS FOR INTERNATIONAL LABOR MIGRATION
}

The article deals with the issues of international labor migration as a phenomenon of the globalization world. A number of trends of modern international labor migration are analyzed. The positive and negative effects of labor migration on the demographic situation, employment and income levels, investment climate in the recipient and labor donor countries are examined. Some recommendations for improvement of the Ukrainian state policy in the sphere of migration labor regulation are offered.

Keywords: globalization, international migration, labor migration, employment, unemployment.

Лучик Світлана, Лучик Маргарита. Сучасні тенденції міэннародної трудової міграції.

Стаття присвячена питанням міжнародної трудової міграциї як феномену глобалізаційного світу. Проаналізовано ряд тендениій сучасної міжнародної трудової міграчії. Досліджено позитивний і негативний впливи трудової міграиії на демографічну ситуачію, рівень зайнятості і доходів населення, інвестиційний клімат в краӥнах-реципієнтах та країнах-донорах робочої сили. Запропоновано окремі рекомендаџії щодо удосконалення української державної політики у сфері міграційного трудового регулювання.

Ключові слова: глобалізачія, міжнародна міграція, трудова міграчія, зайнятість, безробіття. 
Relevance of research topic. In recent decades, society has been deeply affected by global geopolitical, geo-economic and environmental changes. The globalization of the world economy is expressed in the process of transformation of the world space into a single zone, which is open for permanent movement of goods, services, information, and capital. Globalization processes are not only limited to the sphere of economy, but also to a large extent affect all key spheres of society ideology, culture, politics. Most economists are convinced that globalization is an objectively right direction of development, and governments in many developed countries share this belief because, in their view, it enhances social productivity and thus contributes to the well-being of the masses (Pichurin, 2017). Globalization is eroding borders and activating flows of capital, goods and labor.

However, globalization is also an irreversible process that causes economically less developed countries to face the same problems. Among these problems are the slowdown in economic growth and the sharp widening of the gap between developed and developing countries that threatens the sustainable development of the economy as global capital plays an increasing role in economic processes. According to the economist O. Krasulina (Krasulina, 2016), the model of the global world order, which was formed at the present stage, does not contribute to solving the problem of economic inequality between states, but, on the contrary, exacerbates it and leads to widening the gap in the level of economic well-being between different world regions.

Globalization processes, combined with rapid changes in global political and economic systems, have also contributed to the sharp intensification of global migration flows, which has led to the formation of a fundamentally new migration situation in the world.

Formulation of the problem. International migration, in particular labor, is becoming an important form of international economic relations, determining the development of national labor markets, high technology, capital, social sphere and so on. Demographic aging of the population in developed countries, formation of stable demand for migrant labor, significant financial flows in the form of remittances of migrants - all this leads to an increase in international migration of the population, expansion of its geography and influence on political, economic, social, cultural and ethnic processes in the world.

Analysis of recent researches and publications. I. Kurylo, E. Libanova, O. Malynovska, M. Semykina, O. Pozdniak, L. Chervinska paid attention to the problem of international labor migration. Their scientific works reveal the main causes, tendencies and consequences of migration processes, allow us to explore the migration policies of states. However, this problem needs further investigation in the light of current trends.

Presenting main material. According to many domestic and foreign economists, migration is an objective and necessary attribute of the modern world. 
International labor migration is the displacement of able-bodied people from one country to another in search of work and better living conditions. Today, virtually every country is either a labor donor, or used for transit of human flows, or is a recipient country. Moreover, countries that participate in international migration inevitably find themselves influenced by its effects, both positive and negative.

Migration has the most significant impact on the demographic situation in developed countries, which is characterized by declining birth rates and increasing life expectancy. The aging of the population has led to an increase in health care costs and pensions, while the number of employees has been steadily declining. In order to maintain a stable population, the birth rate should be kept at 2.2 children per woman. However, in many countries, the figure has fallen below 2, leading to the risk of becoming a demographic time bomb as is stated by the Science Alert writes (Noryna, 2018).

The most difficult demographic situation is in Europe. In a number of European countries, including Bulgaria, Bosnia and Herzegovina, Hungary, Latvia, Lithuania, Republic of Moldova, Serbia, Ukraine, Croatia and Japan, the population will decrease by more than $15 \%$ by 2050 (Unites Nations, 2018).

As for the average life expectancy at birth, the UN estimates that this figure will increase from 72.6 years in 2019 to 77.1 in 2050 . Currently there is a significant gap in the life expectancy in different countries. In 2019, life expectancy at birth in the least developed countries of Africa was 7.4 years below the world average, caused by high rates of infant and maternal mortality, as well as high levels of violence, conflict situations and the ongoing HIV epidemic in these countries (Unites Nations, 2018).

Overall, the United Nations projected that the world's population will increase to 8.5 billion by 2030, 9.7 billion by 2050 and 11.2 billion by 2100 .

Concerning the problem of population decline in most European and other developed countries, it should be noted that this leads to a significant labor shortage. As the mechanism of international migration is a redistribution of labor resources, without which neither the recipient countries nor the donor countries can do without, so all these countries find themselves in a relationship of interdependence, which pushes them to find partnerships and strengthen integration. In the last decade, most of Europe, North America and Oceania have been the main recipients of international migrants. Between 2010 and 2015, the average annual net inflow of migrants to Europe, North America and Oceania was 2.8 million. In the period 2010-2020, more than one million migrants per year will be located in 14 countries and regions. At the same time, migrants will be exiting in 10 countries (Unites Nations, 2018). Of the 258 million international migrants in 2017, 106 million were born in Asia; 61 million in Europe; 38 million - in Latin America and the Caribbean; 36 million in Africa; 4 million in North America; 2 million - in Oceania (Mirkina O.N., 2018). According to the Ministry of Social Policy of Ukraine, in 2018, 7-9 million citizens worked 
outside Ukraine. The number of Ukrainians abroad is estimated at more than 3 million people. The main recipient countries of the Ukrainian workforce are Poland (38.9\%), the Russian Federation (26.3\%), Italy (11.3\%), and the Czech Republic (9.4\%). Other countries where significant migration flows from Ukraine are directed are the United States of America (1.8\%), Belarus (1.7\%), Portugal (1.6\%), Hungary (1.3\%), Israel $(1.1 \%)$, Finland $(1.0 \%)$ and Germany $(0.8 \%)$. Women are more likely to work in Poland (42.6\% vs $37.3 \%)$ and Italy (27.0 vs $4.7 \%)$, while men work in Russia $(31.0 \%$ vs $15.1 \%$ ). In general, the migration activity of men is higher than that of women (7.0\% vs $2.7 \%$ between the ages of 20-64) (Ptoukha Institute for Demography and Social Studies of the National Academy of Sciences of Ukraine. 2018)

Labor migrants are characterized by employment in the household, business and entrepreneurship, construction. Preferably, it is unskilled or low-skilled labor, the mass use of which has been made possible by the weakening of the visa regime. However, the demand for highly qualified staff is increasing. The weakening of qualification requirements for foreign personnel in a number of countries (Germany, Israel, Czech Republic and others) enabled migrants to find employment in high technology, medicine, education and transfer their professional experience, knowledge and skills. At the same time, foreign employers offer relatively high salaries to our compatriots with the provision of a social package and assistance with the new location. For many Ukrainian highly qualified specialists and scholars, moving to the EU is a great opportunity for self-realization. Some are moving with their families, some are starting a family abroad.

It is worth noting that in recent years in Poland, Germany, the Czech Republic, Austria, the USA, Canada, Italy, Spain, Slovakia, jobs are being filled by qualified staff at the expense of foreign students who have studied and received education in one of these countries. Six to nine thousand Ukrainian students go to Poland every year. According to the latest data from Selectivv, 55\% of foreign students in Poland are Ukrainian. Today, over 35,000 Ukrainians study there (TSN.UA, 2019). Students who want to get a quality natural or technical education mostly choose Germany. These are more than 10 thousand young Ukrainians. In Slovakia, Ukrainian students make up almost a third of foreigners studying in Vichy. The vast majority of them study for the state budget, but pay for accommodation. As for Russia, the teaching of Ukrainian students is a political rather than an economic issue. According to the latest data, more than 11,000 Ukrainian students study in Russia (Matsko O., 2019).

Thus, on the one hand, Ukrainian and other foreign students support the economy of the country by paying for tuition and accommodation, and on the other compensate for the outflow from higher education of domestic students, who increasingly choose institutions of study in other EU countries.

Thus, the contribution of international migrants to the economy of recipient countries in terms of remittances, innovations, investments, as well as the transfer of 
technology, professional experience and knowledge, is becoming increasingly tangible. For Ukraine, the income from labor migrants in 2018 amounted to $\$ 11$ billion, which is several times higher than the investment in our country. While migrants' cash flows totaled $\$ 7.5$ billion in 2016, $\$ 9.3$ billion in 2017. It is estimated by the National Bank that it is $8 \%$ of GDP. According to an estimate by the International Organization for Migration (IOM), the amount of «labor» transfers to Ukraine in 2017 exceeded \$ 12 billion, which is up to $11 \%$ of our GDP (UNIAN. 2019). These funds help to keep the country's balance of payments afloat, saving the hryvnia.

However, international migration cannot be considered as a positive phenomenon only. In the recipient countries, the increase in the number of migrant workers causes: the spread of illegal employment, unemployment among the local population, increased costs of social assistance to unemployed migrants, increased government spending on migration policy, capital losses associated with remittance and wage law criminalization of certain sectors of the labor market.

It is very difficult to determine the real scale of illegal employment of migrants in any country. Most often, the illegal work of migrants is used in small businesses to reduce the cost of workers' salaries and training. This brings far greater benefits to employers than legal employment. However, workers themselves may find themselves in harmful working conditions with the need to carry out work that is hazardous to life and health, with a lack of safety. In addition, the illegal employment of migrants is characterized by long hours working day, week, and, as a rule, a late and incomplete payment of wages.

Contemporary refugees, regardless of the reasons and motives for their migration, are increasingly augmenting much of the illegal migrants. First, they are staying in countries with high social standards. Over the first 4 months of 2019, over 206,000 people first applied for asylum in the EU. Most of the applications came from residents of Syria, Venezuela and Afghanistan. Most often, refugees choose countries closest to the African continent - Spain (38911 people in 2018), Greece (22348 people) and Italy (20692 people) (TSN.UA, 2019).

Some European countries (the Czech Republic, Hungary, Poland, Slovakia) refuse to accept refugees from Africa and the Middle East, as such illegal migration leads to a host of negative socio-economic and political problems. For example, the Czech Republic refused to accept refugees because more than 70,000 Ukrainians were already living in the country. The situation is similar in Poland, where in 2018 there were more than 1 million Ukrainians. The use of Ukrainians is not only economically beneficial for these countries, but they are also closer in value to the local population in terms of cultural and spiritual values. The European Union is trying to solve the problem of refugees by dramatically changing the patterns of immigration regulation in the vast majority of major migrant reception countries. Moreover, it is not only Europe and the Anglo-Saxon countries, but also the Persian Gulf, East and Southeast 
Asia. Increasing funding for troubled countries is underway as well as the construction of special centers for migrants in North Africa.

The main negative consequences of international labor migration for labor donor countries are the reduction of demographic, labor potential, the decline in the quality of human resources in the industries of the national economies, the loss of GDP due to the costs of training skilled and highly qualified personnel, who then migrated abroad.

According to the Institute of Demography and Social Research of the National Academy of Sciences of Ukraine, the population of Ukraine including Donbass, but excluding Crimea, will decrease from the current 42.2 million people to 39.5 million by the beginning of 2031. Working population (by European standards aged from 20 to 64 years) will decrease from current figures of 26.9 million to 24 million people due to the outflow of labor abroad. For comparison: according to the data of the last AllUkrainian census of 2001 the population of Ukraine accounted for 48 million 415 thousand people) (Ptoukha Institute for Demography and Social Studies of the National Academy of Sciences of Ukraine, 2019).

According to the State Statistics Service of Ukraine, in 2018 the economically active population was only $42.6 \%$, or 17.9 million. The share of pensioners in the country is almost $27.8 \%$ (11.7 million people) and the economically inactive population - 25.4\% (10.7 million people) (State Statistics Service of Ukraine, 2019). In keeping with these trends, Ukraine is very quickly experiencing a shortage of labor resources in the labor market. Already, more than a third of Ukrainian enterprises have a shortage of staff caused by demographics and labor migration. According to the forecasts of the International Monetary Fund, Ukraine will lose about 15\% of its labor force by 2030, and in 2050 it will fall by $30 \%$. Among all Central and Eastern European countries, the worst situation is only in Latvia and Bulgaria (TSN.UA, 2019).

Because of labor migration, the state loses not only labor but also intellectual resources. The emigration of scientists and highly qualified specialists, the so-called «brain drain» is a serious threat to the country's intellectual security, which is determined by the level of development of scientific potential and intellectual resources, that is, the state of training of able-bodied carriers of scientific intelligence, the number of specialists and scientists, people with higher education (Marutyan R., 2017).

Conclusion. Thus, nowadays, international migration is becoming more widespread, and it facilitates the exchange of knowledge and capital, and enables every person the freedom to move. However, migration, particularly labor, is complex and ambiguous. The entry of migrant workers into countries, on the one hand, contributes to the mitigation of demographic situations and employment problems on the other hand, and causes unemployment among the local population and may create 
some social tension. For the donor countries, massive migration flows of the working population are extremely dangerous as they deepen demographic problems, lead to labor shortages, loss of intellectual capacity, and decrease in budget revenues due to the reduction in the number of potential taxpayers and so on.

For Ukraine, these problems are very topical and pose a threat to economic and even national security. Considerable investments and a long period are needed to change the situation and return Ukrainians to their homeland. First, the national economy needs technological and innovative development to be more competitive. Business conditions in the country need to be improved in order to expand and create decent-paying jobs. There is also a need to significantly improve funding for science and education in order to maintain the existing and further development of scientific, technical and human resources.

\section{REFERENCES}

1. Krasulina O. (2016) The influence of geoeconomics and geopolitics on world development. Economics and Management: Scientific and Practical Journal, 3(131), pp. 53-55.

2. Marutyan R. $(2017,05,28)$ Brain drain is a threat to national security. Matrix. Retrieved from https://matrix-info.com/2017/05/28/vytik-mizkiv-zagroza-dlya-natsionalnoyibezpeky-i/

3. Matsko O. $(2019,01,31)$ Education in Russia. How an aggressor country lures Ukrainian students to its universities. Polit.UA. Retrieved from https://politua.org/gumanitarnaya-aura/57865-obrazovanie-v-rossii-kak-strana-agres/

4. Mirkina O.N. (2018) Trends in contemporary international labor migration. Economic journal, 3(51), pp. 92-107.

5. Noryna A. $(2018,08,09)$ Countries that can turn into demographic bombs are named. Vzglyad. Retrieved from https://vz.ru/news/2018/8/9/936393.html.

6. Pichurin, I.I. (2017) The impact of globalization on economic development. Ekaterinburg: Publishing House of the UMC UPI, $110 \mathrm{p}$.

7. Ptoukha Institute for Demography and Social Studies of the National Academy of Sciences of Ukraine (2019). Bushfire resources: Institute of Demography and Social Research of the National Academy of Sciences forecasts population decline in Ukraine. Retrieved from https://idss.org.ua/index.

8. Ptoukha Institute for Demography and Social Studies of the National Academy of Sciences of Ukraine (2018). Bushfire resources: Ukrainian Society: The Migration Dimension: Nat. report. Retrieved from https://www.idss.org.ua/arhiv/ Ukraine_migration.pdf. 
9. State Statistics Service of Ukraine (2019). Bushfire resources: Economic Activity of Population in Ukraine 2017: Statistical publication. Retrieved from http://www.ukrstat.gov.ua/.

10. TSN.UA (2019). Bushfire resources: Every year in Poland, the number of Ukrainian students increases: what attracts education abroad. Retrieved from https://tsn.ua/ukrayina.

11. TSN.UA (2019). Bushfire resources: How many refugees fled to the European Union in 2018. infographics. Retrieved from https://tsn.ua/ukrayina.

12. TSN.UA (2019). Bushfire resources: By 2050, Ukraine will lose more than a third of its workforce: what it will affect and how to fix it. Retrieved from https://tsn.ua/ukrayina.

13. UNIAN (2019) Bushfire resources: The economy is trapped. New records of labor migration. Retrieved from https://www.unian.net/economics/finance/.

14. Unites Nations (2018) Bushfire resources: Population. Retrieved from https://www.un.org/ru/sections/issues-depth/population/index.html. 